\title{
COMPARATIVE STUDY OF PHASES FORMED DURING HCFEMN UNDER CO AND CARBON: PREREDUCTION
}

\author{
Michel Kalenga WA KALENGA, Didier Kasongo NYEMBWE \\ University of Johannesburg, Department of metallurgy, School of Mining Metallurgy and Chemical \\ EngineeringFaculty of Engineering and The Built Environment, South Africa \\ dnyembwe@uj.ac.za, michelk@uj.ac.za
}

https://doi.org/10.37904/metal.2019.668

\begin{abstract}
During High Carbon Ferromanganese production, the understanding of phases formation is of vital importance since they determine the quality of the overall operations in the furnace. This is also strongly dependent on the chemical composition of the feed. As opposed to other manganese ores that are acidic, South Africa has a basic manganese ore. The formation of phases during HCFeMn from still needs more investigation since it has been found that some theories do not explain what is observed in the South African manganese industry. The current work compared the phases that formed in the prereduction zone when carbon was used as opposed to carbon monoxide being blown into the furnace. Manganese ore from Nchwaning was used in the current work. Coke containing $86 \%$ fixed carbon and a bottle containing CO with $98 \%$ purity were used. The basicity was adjusted to 1 through addition of silica. The ore and the flux were crushed and milled together for better homogenization of the feed. XRD, XRF and SEM were used to characterize the feed and the products. The working temperatures were from $1200^{\circ} \mathrm{C}$ to $1300^{\circ} \mathrm{C}$ with $50^{\circ} \mathrm{C}$ increment. Graphite crucible was used for the experiments. To ensure that products analysed were not from the interaction with the crucible, only samples from the centre of the crucible were considered. Experiments were conducted in an alumina tube furnace for two hours after reaching the aimed temperature. Although carbon monoxide was blown into the furnace at a rate to ensure more reducing conditions that would presumably prevail same than when using carbon, results show similarities in the phase composition but the $\mathrm{MnO}$ content differed considerably.
\end{abstract}

Keywords: Ferromanganese, Prereduction, phases comparison

\section{INTRODUCTION}

The production of High carbon ferromanganese requires a vast amount of data to understand different mechanisms during operations in the furnace. Generally speaking, the quality of products is dependent on the feed [1-3]. A better quality of products must be achieved on one hand and the energy consumption must be monitored on the other hand. Both have been reported to be directly dependent on the quality of the manganese ore [4-8]. Investigations have also shown that the degree of prereduction could be as high as $60 \%$ and that the chemical composition of the manganese ore had a remarkable on the degree of prereduction [9]. The rate of $\mathrm{MnO}$ reduction from a slag of high carbon ferromanganese was investigated. It was found that graphite that was used for reduction had an effect and depended on the properties of the graphite [10]. Another study conducted on the reduction kinetics of manganese oxide has shown that carbon monoxide gave a higher reduction rate than argon although the expectation was that argon should have provided a high driving force [11]. The same study showed that charcoal gave a higher rate of reduction as opposed to coke. The above gave an indication that different atmospheres created by different reductants or different sources of carbon played an important role. Investigations on the kinetics of a number of manganese oxides ores have revealed that the temperature and the nature of the ore determined the degree of reduction [12]. The correlation between time and percentage reduction was found to be directly proportional [13]. The medium of reduction as well as the crucible used have been found to have an impact on the reduction rate of $\mathrm{MnO}$ [14-17]. Early investigations of reduction of pyrolusite in the temperature range of $250-450^{\circ} \mathrm{C}$ under $\mathrm{CO}$ gas have revealed that the reduction went through $\mathrm{Mn}_{3} \mathrm{O}_{4}$ down to $\mathrm{MnO}$ [18]. The current investigation focused on comparing the reduction 
of manganese ore using $\mathrm{CO}$ gas and in presence of coke. Based on different works conducted previously on different manganese ores that were acidic, the current investigation looked at a basic manganese ore from South Africa and the impact of the type of reductant on the quality of the products obtained. Since South Africa has the $70 \%$ world reserves of manganese, but only contribute with $30 \%$ of the world production, it was imperative that thorough investigations be conducted in order to improve the productivity [19].

\section{EXPERIMENTAL PROCEDURE}

\section{Materials}

In this work, a basic manganese ores from South Africa were used for the investigation. Silica was used as flux. Graphite crucible, silica crucible used to hold the graphite crucible to avoid spillages if it so happened. A bottle of carbon monoxide provided by Afrox was used for reduction. A vertical alumina tube furnace heating at a rate of $7{ }^{\circ} \mathrm{C} / \mathrm{min}$ was used in this investigation. XRF, XRD and SEM-EDS were used for characterization of the feed and the products.

\section{Methodology}

For the first type of experiments, the ore was mixed with the required amount of fluxing agent and milled together for 15 minutes to homogenize the sample. For the second type of experiments, the ores was mixed with the flux and coke were milled together for 15 minutes to homogenize the head sample. After homogenization, the head sample was placed in a graphite crucible which in turn was placed in the hot zone of the tube furnace. The experiments were conducted at $1200^{\circ} \mathrm{C}$. After reaching the set temperature, the sample was kept in the furnace for two hours then the furnace was switched off to cool down to room temperature. The feed and the products were analyzed using XRF, XRD and SEM.

\section{RESULTS AND DISCUSSION}

Figure 1 below provides the XRD results of the manganese ore used in the current investigation. The same samples were used in previous investigations conducted by same authors. It was observed that the manganese ore was essentially composed of braunite, hausmanite, bixbyte, hematite, quartz and calcium iron silicate.

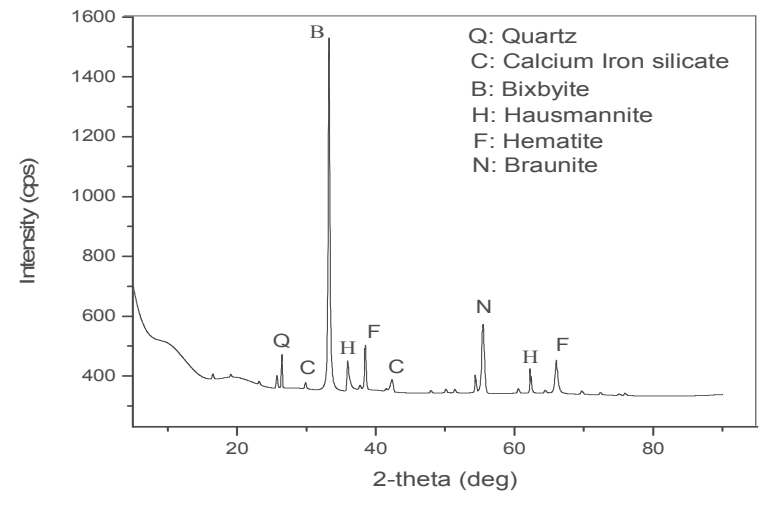

Figure $1 \mathrm{XRD}$ results of the manganese ore [19]

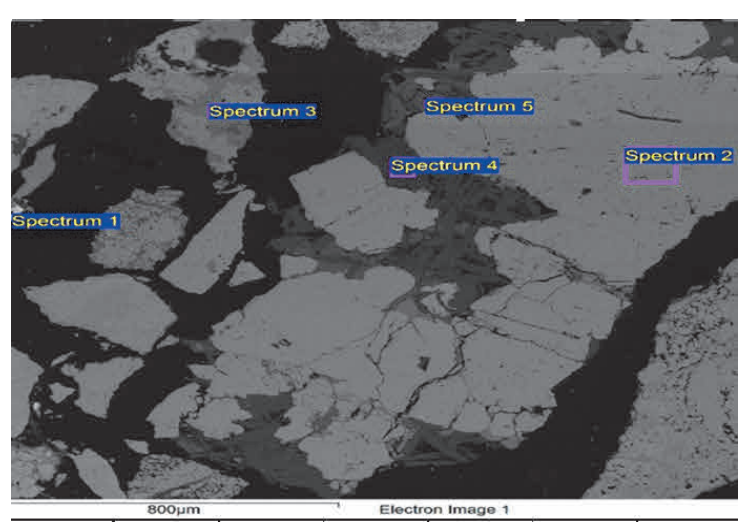

Figure 2 SEM of the manganese ore [20]

Table 1 provides the results obtained with SEM-EDS on the chemical composition of the ore as per micrograph presented in Figure 2 above. 
Table 1 Analysis of the spectra in Figure 2 [20]

\begin{tabular}{|c|c|c|c|c|c|c|c|c|}
\hline Spectrum & $\mathbf{M n}$ & $\mathbf{F e}$ & $\mathbf{A l}$ & $\mathbf{S i}$ & $\mathbf{C a}$ & $\mathbf{M g}$ & Phases & Formulas \\
\hline 1 & 6.7 & - & - & - & 1.05 & - & Braunite & ${\mathrm{Mn} . \mathrm{Mn}_{6}\left(\mathrm{SiO}_{4}\right) \mathrm{O}_{8}}$ \\
\hline 2 & 56.27 & 11.13 & - & 4.07 & 4.01 & - & Bixnyte & $\left(\mathrm{Fe}, \mathrm{Mn}_{2} \mathrm{O}_{3}\right.$ \\
\hline 3 & 1.21 & 15.43 & 1.21 & 20.75 & 22.82 & - & Hausmannite & $\left(\mathrm{Mn}_{3} \mathrm{Fe}\right) \mathrm{O}_{4}$ \\
\hline 4 & 0.46 & 0.57 & 9.87 & 18.25 & - & 24.71 & Calcium iron silicate & $\mathrm{CaFeSi}_{2} \mathrm{O}_{6}$ \\
\hline 5 & 1.1 & - & 2.34 & 3.34 & 53.66 & 7.18 & Quartz & $\mathrm{SiO}_{2}$ \\
\hline
\end{tabular}

The observations made from Table 1 were that the SEM-EDS results were in line with the chemical composition of the ore obtained with XRD spectrum in Figure 2. The presence of braunite, bixbyte, hausmanite calcium silicate and quartz was confirmed. The above results were for the same samples used in previous studies conducted by same authors.

Table 2 XRF analysis of the manganese ore [20]

\begin{tabular}{|l|c|c|c|c|c|c|c|c|}
\hline Oxide & $\mathrm{MgO}$ & $\mathrm{Al}_{2} \mathrm{O}_{3}$ & $\mathrm{SiO}_{2}$ & $\mathrm{CaO}$ & $\mathrm{MnO}_{2}$ & $\mathrm{Fe}_{2} \mathrm{O}_{3}$ & Basicity & $\mathrm{Mn} / \mathrm{Fe}$ \\
\hline Mass (\%) & 1.03 & 0.93 & 4.89 & 5.29 & 66.85 & 19.56 & 1.1 & \\
\hline Element & $\mathrm{Mg}$ & $\mathrm{Al}$ & $\mathrm{Si}$ & $\mathrm{Ca}$ & $\mathrm{Mn}$ & $\mathrm{Fe}$ & & 3.1 \\
\hline Mass (\%) & 0.97 & 0.77 & 3.56 & 5.89 & 65.80 & 21.31 & & \\
\hline
\end{tabular}

The CO gas was provided by Afrox and contained $99.06 \%$ carbon monoxide while the analysis of the coke used in this investigation was provided in Table 3 below.

Table 3 Proximate and ultimate analysis of the reductant

\begin{tabular}{|l|l|l|l|l|}
\hline Parameter & \multicolumn{4}{|l|}{ Proximate analysis (AR) } \\
\hline & Fixed-C & Volatile & Ash & Moisture \\
\hline Coke & 83 & 3.9 & 11.7 & 1.8 \\
\hline
\end{tabular}

From Table 3, it could be seen that carbon fixed is $83 \%$, volatile matters are $3.9 \%$ whereas ash content amounts to $11.7 \%$ and moisture $1.8 \%$. This indicated that the coke used is not of low quality.

The XRD results of products obtained with coke as reductant are provided in Figure 3 below.

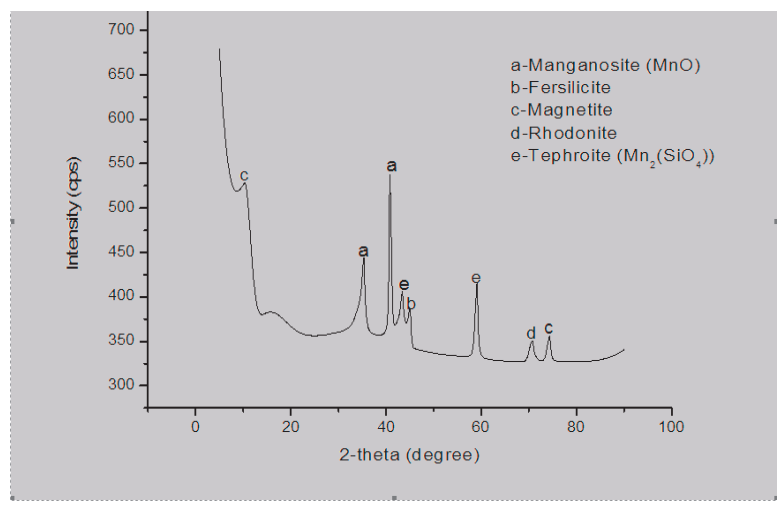

Figure 3 XRD pattern of products obtained at $1200^{\circ} \mathrm{C}$ in presence of coke

From Figure 3, following phases have been identified: rhodonite, silica, iron, tephroite, fayalite manganoan and hausmanite. This indicated that some iron oxides were already reduced to iron while hausmanite was still present in the products. However, tephroite formed as well as rhodonite and slag started to form. 
Figure 4 below gives the SEM results of the products obtaine at $1200^{\circ} \mathrm{C}$ in presence of coke.

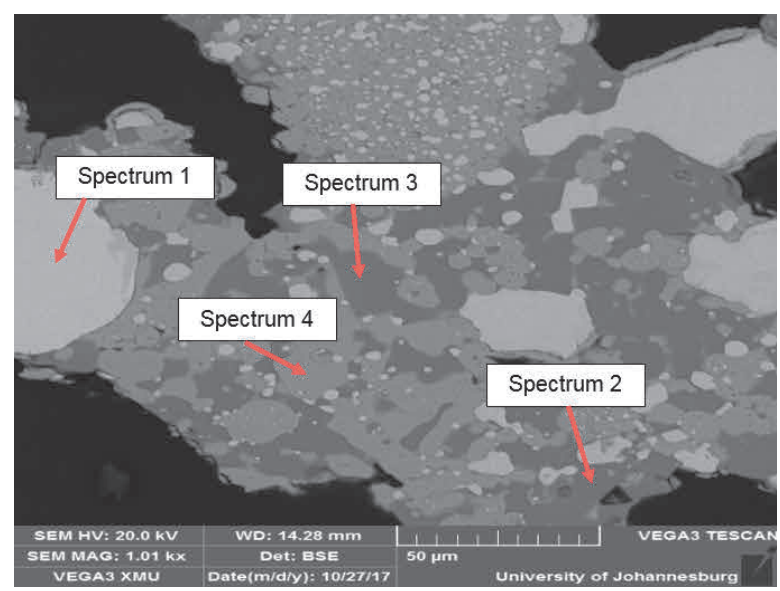

Figure 4 SEM micrograph of the sample reduced at $1200^{\circ} \mathrm{C}$ with coke

Table 4 EDS analysis results of the sample reduced at $1200^{\circ} \mathrm{C}$ with coke

\begin{tabular}{|c|c|c|c|c|c|c|c|c|c|}
\hline \multirow[b]{2}{*}{ Spectrum } & \multicolumn{8}{|c|}{ Weight (\%) } & \multirow[b]{2}{*}{ Phases } \\
\hline & $\mathbf{F}$ & $\mathrm{Mg}$ & Al & Si & $\mathrm{Ca}$ & Mn & $\mathrm{Fe}$ & 0 & \\
\hline 1 & & & & & & 41.34 & 58.66 & & FeMn \\
\hline 2 & 3.24 & & & 15.8 & 15.5 & 30.42 & 0.48 & 33.73 & Rhodonite $\left(\mathrm{MnSiO}_{3}\right)$ \\
\hline 3 & 3.79 & 0.72 & & 11.5 & 11.0 & 40.00 & 2.66 & 30.35 & Tephroite $\left(\mathrm{Mn}_{2} \mathrm{SiO}_{4}\right)$ \\
\hline 4 & 5.71 & 0.57 & 0.38 & 0.40 & 0.58 & 68.38 & 1.32 & 21.79 & Manganosite $(\mathrm{MnO})$ \\
\hline
\end{tabular}

The SEM-EDS results shown in Table 4 confirmed the phases identified with XRD in Figure 4. These phases were namely rhodonite, tephroite and $\mathrm{MnO}$ as well as iron. However, it was observed from the XRD that magnetite was also present. Further, ferromanganese alloy formed at this stage. This was an indication that reduction conditions were strong enough to get part of the ore being reduced down to the alloy. Therefore, it could be assumed that lower oxides of manganese and iron were reduced to obtain the alloy. This was also observed in previous works [7]. But most probably due to its very small amount, the alloy was not detected this was not detected with XRD. It implied that the amount of alloy that formed was very low.

The Figure 5 below provides the XRD pattern of products obtained with the use of carbon monoxide gas only.

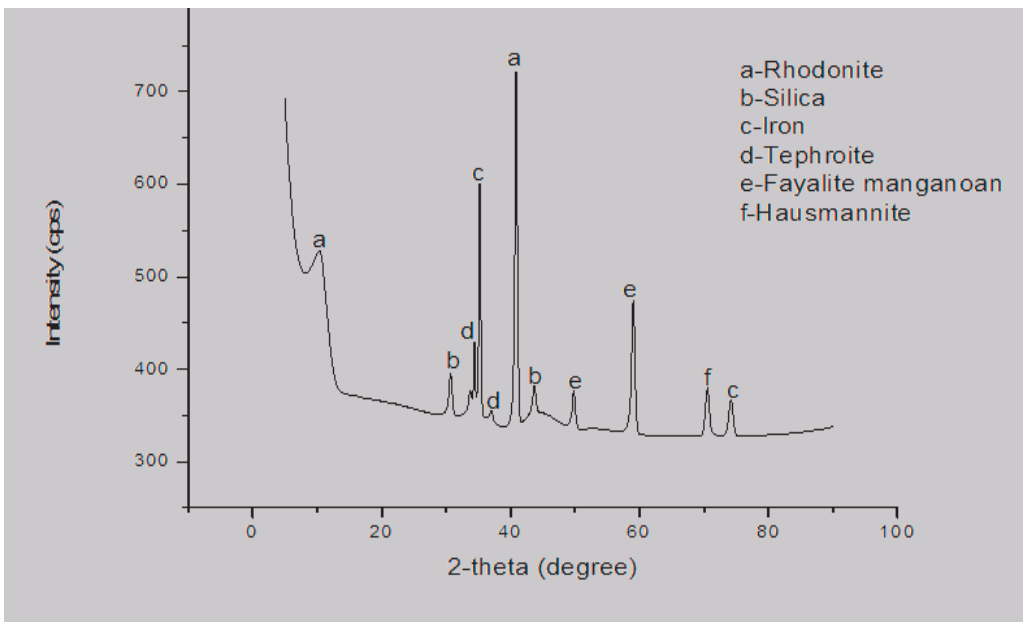

Figure 5 XRD pattern of products obtained at $1200 \mathrm{C}$ with the use of carbon monoxide gas only 


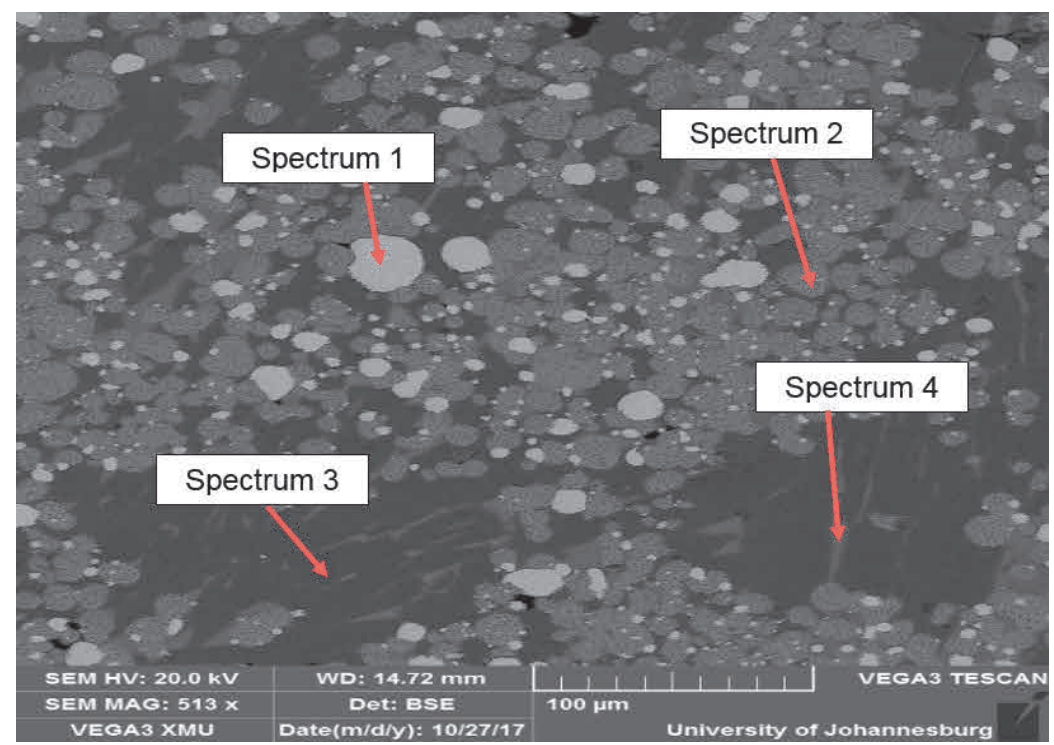

Figure 6 SEM micrograph of the sample reduced at $1200{ }^{\circ} \mathrm{C}$ with carbon monoxide gas only

Table 5 SEM-EDS analysis results of the sample reduced at $1200^{\circ} \mathrm{C}$ with carbon monoxide gas only

\begin{tabular}{|l|l|l|l|l|l|l|l|l|l|}
\cline { 2 - 10 } \multicolumn{1}{c|}{} & \multicolumn{7}{c|}{ Weight (\%) } & \multicolumn{1}{c}{} \\
\hline Spectrum & F & Mg & Al & Si & Ca & Mn & Fe & O & Metal/Phases \\
\hline 1 & & & & & & 54.48 & 46.39 & & FeMn \\
\hline 2 & 5.67 & 1.02 & & 2.35 & 2.13 & 60.26 & 5.31 & 23.27 & Manganosite $(\mathrm{MnO})$ \\
\hline 3 & 3.39 & 0.89 & & 17.2 & 15.7 & 28.16 & & 34.66 & Tephroite $\left(\mathrm{Mn}_{2} \mathrm{SiO}_{4}\right)$ \\
\hline 4 & 3.19 & 0.93 & 0.33 & 16.6 & 16.1 & 28.32 & & 34.51 & Rhodonite $\left(\mathrm{MnSiO}_{3}\right)$ \\
\hline
\end{tabular}

From Table 5, it can be observed that manganosite, tephroite, rhodonite are present in the products. These phases are same that were present in the micrograph of products obtained with coke except magnetite. Also, same as observed with the use of coke, no ferromanganese was detected with the XRD, but identified with the SEM. However, from visual analysis, it was observed that the size of FeMn was bigger when coke was used as reductant than when carbon monoxide was blown in the furnace without coke presence. This led to an observation that, when carbon monoxide was blown into the furnace, the residence time might have been short such that it did not have enough time to reduce the ore. Although measurements were not taken to quantify the amount of reducing gas in the furnace for the two types of atmospheres, it can however be observed that in the prereduction zone only the degree of reduction differed since with coke magnetite also appeared in the products.

\section{CONCULSION}

The current investigation on the influence of coke compared to carbon monoxide used at the same temperature to reduce a manganese oxide ore in the prereduction zone have revealed that:

1) The phases that formed were very much similar. Although the XRD was not able to detect the alloy that formed while SEM results have confirmed the presence of FeMn. This was an indication that although the temperature was relatively low, there was a considerable reduction for the lower oxides of manganese and iron to have the manganese alloy occurring so early.

2) The size of FeMn metal was bigger when coke was used as reductant than when carbon monoxide was blown in the furnace without coke presence. This implied that, when carbon monoxide was blown into 
the furnace, the residence time might have been short such that it did not have enough time to reduce the ore as compared to coke.

3) Although measurements were not taken to quantify the amount of reducing gas in the furnace for the two types of atmospheres, it can however be observed that in the prereduction zone only the degree of reduction differed since with coke magnetite also appeared in the products.

\section{REFERENCES}

[1] YIDRIM, Ireme Z. and PREZZI, Monica. Chemical, mineralogica and Morphological Properties of Steel slag. Journal of Advances in Civil Engineering [Online]. 2011. Vol. 2011, pp. 1-13 [viewed on 2018-12-08]. DOI:10.1155/2011/463638

[2] ANDREW, Nicole J., VAN BEEK, Burger, LEXMOND, Axel Sebastiaan and ZIETSMAN, Johan H. Effect of feed composition fluctuations on a platinum furnace energy balance and slag temperature. The Southern African Institute of Mining and Metallurgy, Pyrometallurgical Modelling, pp. 117-126.

[3] NURJAMAN Fajar, SAPUTRA Hendri, ASTUTI Widi, FERDIAN Deni and SUHARNO Bambang. Ferromanganese production from the mixture of medium-grade and low-grade Indonesian manganese ore. Advances in Materials and Processing Technologies [Online]. 2018. Vol.4. Issue 2, pp.296-302 [viewed on 2018-03-28]. Available from: DOI: $10.1080 / 2374068 X .2017 .1419411$

[4] SITEFANE, M. and KALENGA, M.K. On the possibility of using manganese carbonate ores in ferromanganese industry. Metallurgist, Vol. 62, Nos. 1-2, May, 2018 (Russian Original Nos. 1-2, January-February, 2018). pp.111118

[5] KALENGA, M.; XIAOWEI, P. and TANGSTAD, M. Manganese alloys production: Impact of chemical compositions of raw materials on the energy and materials balance. In INFACON XIII: Thirteen International Ferroalloys Congress. Almaty: KAZAKHSTAN, 2013. pp.647-657

[6] TANGSTAD, M. The Roma project (Resource Optimization and Recovery in The Material Industry) a typical cooperation project in Norway. In SAIMM: Southern African Institute of Mining and Metallurgy, Johannesburg: SOUTH AFRICA, 2011, pp. 209-217

[7] COETSEE, T., ZIETSMAN, J. and PISTORIUS, C. Predicted effect of ore composition on slag formation in manganese ore reduction. Journal, MINERAL PROCESSING AND EXTRACTIVE METALLURGY [Online]. 2014, Vol. 123, Issue 3, pp.141-147 [viewed 2019-02-10]. Available from: DOI: 10.1179/1743285514Y.00000000057

[8] POCHART, G., JONCOURT, L., TOUCHARD, N. and PERDON, C. Metallurgical benefit of reactive high grade ore in manganese manufacturing. In INFACON XI: Eleventh International Ferro Alloys Congress, New Delhi: INDIA, 2007, pp. 217-230.

[9] ISHAK, R. and TANGSTAD, M. Degree of prereduction without coke consumption in industrial furnaces. In INFACON XI: Eleventh International Ferro Alloys Congress New Delhi: INDIA, 2007, pp. 268-280

[10] SAFARIAN, J., KOLBEINSEN, L., GAAL, S. And TRANEL, G. The effect of graphite properties on the Rate of MnO Reduction From High Carbon Ferromanganese slag. In INFACON XI: Eleventh International Ferro Alloys Congress New Delhi: INDIA, 2007, pp. 321-334

[11] TRANELL, G., GALL, S., LU, D., TANGSTAD, M. And SAFARIAN, J. Reduction Kinetics Of Manganese Oxide From HCFeMn Slags. In INFACON XI: Eleventh International Ferro Alloys Congress New Delhi: INDIA, 2007, pp. 232-240

[12] KUMAR, M., RANGANATHAN, S. And SINAH, S.N.Kinetics of reduction of Different Manganese ores. In INFACON XI: Eleventh International Ferro Alloys Congress New Delhi: INDIA, 2007, pp. 241-246

[13] COETSEE, T. The Effect of Processing Parameters on Ferromanganese Alloy Carbon Content in Mamatwan Ore Reduction. Journal, Mineral Processing and Extractive Metallurgy Review 2017, Vol. 38, NO. 2, pp.116-125

[14] UPADHYA, K., "The kinetics and mechanism(s) of manganese oxide reduction from liquid slag by carbon dissolved in iron", ISS Transactions, 7, 1986, pp. 1-6.

[15] XU, K., JIANG, G., DING, W., GU, L., GUO, S. and ZHAO, B., "The kinetics of reduction of MnO in molten slag with carbon saturated liquid iron", ISIJ International, 33,1993, No. 1, pp. 104-108. 
[16] POMFRET, R. J. and GRIEVESON, P., "Kinetics of fast initial stage of reduction of MnO from silicate slags by carbon in molten iron", Ironmaking and Steelmaking, No. 5, 1978, pp. 191-197

[17] DAINES, W. L. and PEHLKE, R. D., "Kinetics of manganese oxide reduction from basic slags by carbon dissolved in liquid iron", Metallurgical Transactions, 2, 1971, pp. 1203-1211.

[18] BERG, K.L. 1999. Low Temperature Reduction of Pyrolusite Ore. STF24 A99584. SINTEF MATERIALS TECHNOLOGY, Trondheim, 10pp.

[19] MHLALUKA, S.; 26 January 2019 00:16. Shining a spotlight on manganese, its rising global demand and SA's readiness to handle it for the next 100 years. [viewed on 2019-03-12]. Available from: https://www.moneyweb.co.za/mineweb/sas-commodity-of-the-year-goes-to-manganese/

[20] MAKHUBELE, C., SINGO, M., KALENGA, M. and Mulaba-Bafubiandi, A.F. Ferromanganese Production: The use of biochar in the reduction of South African manganese ores, preliminary study. In INFACON XV: Fifteenth International Ferro Alloys Congress Cape Town: South Africa., 2018, Proceedings under edition. 